\title{
Ovarian characteristics in sheep with multiple fecundity genes
}

\author{
Kenneth P McNatty ${ }^{1}$, Derek A Heath ${ }^{1}$, Zaramasina Clark ${ }^{1}$, Karen Reader ${ }^{2}$, Jennifer L Juengel ${ }^{3}$ \\ and Janet L Pitman ${ }^{1}$ \\ ${ }^{1}$ Victoria University of Wellington, Wellington, New Zealand, ${ }^{2}$ University of Otago, Dunedin, New Zealand, and \\ ${ }^{3}$ AgResearch, Invermay Agricultural Centre, Mosgiel, New Zealand
}

Correspondence should be addressed to K P McNatty; Email: Kenneth.mcnatty@vuw.ac.nz

\begin{abstract}
Ewes heterozygous for combinations of the Inverdale (FecX'; I+), Booroola (FecB; B+) and Woodlands (FecX2 ${ }^{\mathrm{W}}$; W+) mutations have ovulation rates higher than each mutation separately. The aims of the experiments described herein were to examine the ovarian phenotypes in $\mathrm{I}+\mathrm{B}+$ and $\mathrm{I}+\mathrm{B}+\mathrm{W}+$ ewes and to compare these with the appropriate ++ (controls), $\mathrm{I}+$ and $\mathrm{BB}$ animals available for this study. The mean \pm S.E.M. ovulation rates in the $++(n=23), I+(10), I+B+(7), I+B+W+(10)$ and $B B(3)$ animals were $1.8 \pm 0.1,2.5 \pm 0.2$, $6.6 \pm 1.0,9.6 \pm 0.9$ and $9.7 \pm 0.9$ respectively. The maximum number of granulosa cells per follicle in the ++ and $I+$ genotypes was accumulated after exceeding $5 \mathrm{~mm}$ diameter, whereas in $\mathrm{I}+\mathrm{B}+, \mathrm{I}+\mathrm{B}+\mathrm{W}+$ and $\mathrm{BB}$ animals, this was achieved when follicles reached $>2-3 \mathrm{~mm}$. The number of putative preovulatory follicles, as assessed from those with $\mathrm{LH}$-responsive granulosa cells, $24 \mathrm{~h}$ after the induction of luteolysis, was higher $(P<0.01)$ in the $\mathrm{I}+\mathrm{B}+$ and $\mathrm{I}+\mathrm{B}+\mathrm{W}+$ compared to the ++ and $\mathrm{I}+$ genotypes. The median follicular diameters of these follicles in the,$++ I+, I+B+, I+B+W+$ and $B B$ genotypes were $6,5,3,3$ and 3 mm respectively. The total number of granulosa cells in the putative preovulatory follicles when added together, and total mass of luteal tissue, did not differ between the genotypes. Thus, despite large ovulation rate differences between animals with one or more fecundity genes, the total cell compositions over all preovulatory follicles and corpora lutea, when added together, are similar to that from the one or two such follicles in the wild types.

Reproduction (2017) 153 233-240
\end{abstract}

\section{Introduction}

Over the past 15 years, an extensive range of genetic mutations have been identified in sheep that affect both ovulation rate and litter size (Juengel et al. 2013, Souza et al. 2014). Most of these mutations have been located in genes of the transforming growth factor beta (TGFB) superfamily or a related receptor. The most prevalent of these are inactivating mutations present within the bone morphogenetic protein 15 (BMP15) or growth differentiation factor 9 (GDF9) gene. The ovulation rate phenotypes for the heterozygous and homozygous BMP15 and GDF9 mutations that lead to increased ovulation rate and sterility respectively, can be replicated by partial or full immuno-neutralisation of the BMP15 or GDF9 proteins in vivo (Juengel et al. 2002, 2004). In addition to the aforementioned growth factors, a point mutation (Q249R) in the type I BMP receptor, $(B M P R 1 B)$ also known as activin-receptor-like kinase 6 (ALK6), increases ovulation rate in both the heterozygotes and homozygotes of animals referred to as Booroola (B) sheep. This mutation alters the signalling response to BMP ligands in vitro and reduces the level of BMP15 but not GDF9 mRNA (Fabre et al. 2003, Campbell et al. 2006, Crawford et al. 2011). Within the ovary, BMP15 and GDF9 are expressed in oocytes but not cumulus cells in sheep, cattle, rats, mice, pig and deer (Crawford \& McNatty 2012). In other reports, BMP15 and GDF9 mRNA was detected in cumulus and/or granulosa cells of cattle, goats and pigs using qPCR (Silva et al. 2004, Paradis et al. 2009, Hosoe et al. 2011). In these studies, validation of intact, undamaged oocytes from individual follicles from which cumulus or granulosa cells were recovered was not described. Therefore, without this key control, these findings will need further validation to eliminate the possibility of false positives (Mester et al. 2015). In contrast, BMPR1B is known to be expressed more widely in the ovary including oocytes, granulosa cells and theca cells (Wilson et al. 2001). In addition to the above mutations, there is another, yet to be identified, X-linked mutation (Davis et al. 2001), that has been found in Woodlands (W) ewes $\left(\mathrm{FecX} 2^{\mathrm{W}}\right)$ : both the heterozygous and homozygous carrier animals have higher ovulation rates and litter sizes (Davis et al. 2001, 2005). Interestingly, in these animals, the expression levels of BMP15 and $B M P R 1 B$ mRNA were both lower, those of $A L K 5$ mRNA was higher and GDF9 and BMPR2 mRNA were not different from the wild type (Feary et al. 2007). 
Sheep carrying various heterozygous combinations of some of these mutations appear to have either additive or multiplicative effects on ovulation rate compared to the wild types (++). For example, in animals heterozygous for both the Inverdale variant of the BMP15 mutation $(\mathrm{I}+$ ) and the BMPR1B (Booroola, $\mathrm{B}+$ ) mutation (i.e. I+B+ animals), the mean ovulation rate was found to be $267 \%$ above that for the ++ , whereas for $\mathrm{I}+$ and $\mathrm{B}+$ ewes, the increases were $67 \%$ and $132 \%$ respectively (Davis et al. 1999). Animals with the three mutations, $\mathrm{I}+\mathrm{B}+\mathrm{W}+$ also appear to be at least additive with ovulation rates as high as 13 compared to 1-2 for the wild type (Davis et al. 2008). The additive or multiplicative effect of these genes may be related to a reduction in BMP15 concentrations as lower BMP15 expression levels in oocytes have been shown in the BB and $\mathrm{W}+$ genotypes.

Investigations of the ovarian phenotypes in the heterozygous and homozygous Booroola mutant animals $(\mathrm{B}+/ \mathrm{BB})$ indicate that follicles reach preovulatory diameters at consistently smaller sizes than in the wild type. This maturation at smaller follicular diameters is also accompanied with fewer granulosa cells per follicle and an earlier acquisition of $\mathrm{LH}$ responsiveness by the granulosa cells as measured by cAMP output in vitro (McNatty et al. 1986, Henderson et al. 1989). The acquisition of LH receptors by granulosa cells is known to be a key marker for identifying the presumptive preovulatory follicle (Webb \& England 1982). Moreover, this maturation of the preovulatory follicle at a smaller diameter occurs in BB animals with no change in $\mathrm{FSH}$ receptor-binding characteristics, or FSH responsiveness, with respect to cAMP synthesis (McNatty et al. 1989, Crawford et al. 2011). For the heterozygous Inverdale phenotype (I+), the acquisition of $\mathrm{LH}$ responsiveness by granulosa cells was also obtained in some follicles at smaller diameters, whereas other follicles were at a similar size to those in ++ animals (McNatty et al. 2009). In general, the numbers of granulosa cells for a given follicular diameter in the I+ genotype were lower than that in the ++ animals (Shackell et al. 1993). Additionally, the acquisition of $\mathrm{LH}$ receptivity in granulosa cells also occurred without any change in FSH receptor-binding characteristics or FSH responsiveness with respect to cAMP synthesis (McNatty et al. 2009). In both Booroola and Inverdale ewes, the changes in ovarian phenotype associated with increases in ovulation rate were not associated with any overall change in ovarian secretions of oestradiol during the follicular phase and/or progesterone during the luteal phase (McNatty et al. 1986, Shackell et al. 1993). With regards to the heterozygous or homozygous Woodland-mutant ewes (W+ or WW), little is known about the cell numbers or functional properties of the developing antral follicles with respect to $\mathrm{LH}$ and $\mathrm{FSH}$ responsiveness by granulosa cells. However, it is known that the proportion of non-atretic antral follicles, but not total number of follicles, is higher in $\mathrm{W}+$ than in ++ animals. Moreover, when the oocytes of the antral follicles in the $\mathrm{W}+$ ewes were expressed as a fraction of the follicular diameter, they were significantly larger (Feary et al. 2007).

The aims of the experiments described herein were to examine, in more detail, the ovarian phenotypes in $\mathrm{I}+\mathrm{B}+$ and $\mathrm{I}+\mathrm{B}+\mathrm{W}+$ ewes and to compare these with the appropriate ++ controls and with $\mathrm{I}+$ and $\mathrm{BB}$ animals that were available for this study. Given the possibility that the BMP15 protein levels might be lower in all the mutant genotypes, the hypothesis being tested was that each of the heterozygous genetic mutations $(\mathrm{W}+$, $\mathrm{B}+$ and $\mathrm{I}+$ ) when present in individual animals, would increase ovulation rate by increasing the proportion of follicles maturing at smaller diameters and with fewer numbers of granulosa cells that develop an earlier responsiveness to $\mathrm{LH}$ with respect to CAMP synthesis. It is also hypothesised that the total mass of corpora lutea formed for each genotype would not differ from that in the wild type.

\section{Materials and methods}

\section{Animals}

All experiments were performed with the approval of the AgResearch Invermay Animal Ethics Committee in accordance with the Animal Welfare Act Regulations of New Zealand. The animals in this study were mixed-aged ewes, primarily with a Romney background, consisting of ++ (controls, $n=23), 1+$ $(n=10), \mathrm{I}+\mathrm{B}+(n=7), \mathrm{I}+\mathrm{B}+\mathrm{W}+(n=10)$ and $\mathrm{BB}(n=3)$ ewes. The presence or absence of the Booroola mutation and the Inverdale mutation were determined through genotyping (GenomNZ, Mosgiel, New Zealand; www.genomznz.co.nz). The background ovulation rate of the homozygous Booroola flock ranged from 4 to 13 . Whether this flock contains another, as yet unidentified, genetic mutation has not been determined. Ewes carrying the Woodlands mutation, which is present on the $\mathrm{X}$ chromosome, were generated using phenotyped Woodlands carrier rams as described (Davis et al. 2001). Some of the $\mathrm{I}+\mathrm{B}+$ ewes $(n=3)$ and all of the $\mathrm{I}+\mathrm{B}+\mathrm{W}+$ ewes were progeny of Romney ewes crossed with sires that were half Coopworth-Texel and 13 of the aforementioned ++ control ewes contained the same background. Animals with the $\mathrm{W}+, \mathrm{B}+$ genotypes were not available and only two $\mathrm{W}+\mathrm{l}+$ animals were available for this study: the data for the $\mathrm{W}+\mathrm{I}+$ animals are only briefly referred to in the results. The animals in this study had access to pasture and water ad libitum. All animals, during the breeding season, were synchronised with two PGF2 $\alpha$ (cloprostenol; Bayer Animal Health, Auckland, New Zealand) injections 10 days apart. Oestrus checks were undertaken after the second PGF2 $\alpha$ injection to ensure the animals had synchronised. The ovaries were recovered $24 \mathrm{~h}$ after a third PGF2 $\alpha$ given 9-12 days after the second injection. The variation in timing of the third PGF2 $\alpha$ injection was to ensure that only ovaries from three sheep per day were available for follicular dissection. Irrespective of the timing of 
the third injection, the progesterone concentrations at ovarian removal, had declined by $>75 \%$ relative to the levels at the time of the third injection. The time between recovery of the ovaries and initiation of follicular dissection was $<30 \mathrm{~min}$.

\section{$F S H$ and $L H$ reagents}

An in-house highly purified ovine FSH preparation (oFSH Wal) was used to test $\mathrm{FSH}$ responsiveness of granulosa cells (Moore et al. 1997, Fidler et al. 2003). This preparation was $>90 \%$ pure with a bioactivity of $1.4 \times$ USDA-oFSH-10-SIAFP $\mathrm{RP} 2$ or $33,000 \mathrm{IU} / \mathrm{mg}$ when the second human $\mathrm{FSH}$ reference preparation $78 / 549$ was used as the standard in a radioreceptor assay. The level of $\mathrm{LH}$ contamination was $<0.002 \%$ as determined by bioassay. The LH preparation used to test $\mathrm{LH}$ responsiveness of granulosa cells was an hCG preparation (CR121; 13,450 IU/mg; NICHD, Bethesda, MD, USA).

\section{Ovarian studies}

Ovaries were transported to the lab in warmed saline $\left(37^{\circ} \mathrm{C}\right)$, rinsed briefly in $70 \%$ ethanol to remove any bacterial contamination, and then in saline before being immersed in dissection media (DM2; Dulbecco's MEM with $0.1 \%$ bovine serum albumin (BSA; ICPbio Ltd, Auckland, New Zealand), $20 \mathrm{mM}$ Hepes buffer and $0.2 \mathrm{nM} 3$-isobutyl-1-methylxanthine). Apart from BSA, all other media reagents were obtained from Sigma-Aldrich. All ovaries were weighed and then all corpora lutea were individually dissected and weighed. Thereafter, all follicles $\geq 1.0 \mathrm{~mm}$ diameter, in all animals, were individually dissected and their diameters were measured. Subsequently, each follicle was placed in a separate petri dish $(35 \mathrm{~mm}$ diameter) and punctured to release the follicular fluid, most of which was removed without extracting the oocyte-cumulus cell complex (COC) or granulosa cells. Thereafter, $1 \mathrm{~mL}$ of the above-mentioned DM2 media was added and the COC was located and classified based on their morphological appearance. Thereafter, each COC was transferred into a well of a four-well culture dish, (Nunc, Thermo Scientific) containing $0.5 \mathrm{~mL}$ of HEPES-buffered M199 media with $0.1 \mathrm{M}$ kanamycin and $0.04 \% \mathrm{BSA}$ and maintained at $38^{\circ} \mathrm{C}$. The COCs were used for a separate study and not included herein. Once the COC was removed, the granulosa cells were carefully isolated by dispersal from the internal follicular wall using a platinum loop and then an aliquot was counted by haemocytometer. Removal of the granulosa cells under a dissecting microscope made it possible to ensure that damage to the internal follicular wall
Table 1 Effect of genotype on ovulation rate, mean $\mathrm{CL}$ weight per ewe and total CL weight per ewe.

\begin{tabular}{lccc}
\hline Genotype $(n)$ & Ovulation rate & $\begin{array}{c}\text { Mean individual } \\
\text { weight of } C L \\
\text { per ewe }(g)\end{array}$ & $\begin{array}{c}\text { Mean total } \\
\text { weight of } C L \\
\text { per ewe }(g)\end{array}$ \\
\hline$++(23)$ & $1.8 \pm 0.1^{\mathrm{a}}$ & $0.490 \pm 0.027^{\mathrm{a}}$ & $0.896 \pm 0.048^{\mathrm{a}}$ \\
$\mathrm{I}+(10)$ & $2.5 \pm 0.2^{\mathrm{b}}$ & $0.377 \pm 0.035^{\mathrm{c}}$ & $0.801 \pm 0.054^{\mathrm{a}}$ \\
$\mathrm{I}+\mathrm{B}+(7)$ & $6.6 \pm 1.0^{\mathrm{c}}$ & $0.105 \pm 0.012^{\mathrm{d}}$ & $0.816 \pm 0.086^{\mathrm{a}}$ \\
$\mathrm{I}+\mathrm{B}+\mathrm{W}+(10)$ & $9.6 \pm 0.9^{\mathrm{d}}$ & $0.108 \pm 0.022^{\mathrm{d}}$ & $1.107 \pm 0.136^{\mathrm{a}}$ \\
$\mathrm{BB}(3)$ & $9.7 \pm 0.9^{\mathrm{d}}$ & $0.117 \pm 0.032^{\mathrm{d}}$ & $1.123 \pm 0.384^{\mathrm{a}}$ \\
\hline
\end{tabular}

Values are means \pm S.E.M. Numbers in columns not sharing common alphabetical superscripts are significantly different from one another: avb, $P<0.05$; all other comparisons were $P<0.01$.

$n$, number of ewes; g, grams.

was negligible. When isolating granulosa cells from individual follicles, the following variables were recorded namely: the extent of vascularity of the follicle wall; presence or absence of debris in follicular fluid; the total number of granulosa cells recovered and the morphological appearance of the COC (i.e. intact COC, few cumulus cells, misshapen oocyte etc.; McNatty et al. 1986).

\section{Granulosa cell incubation and cAMP assay}

The isolated granulosa cells from each follicle in $1 \mathrm{~mL}$ of DM2 media were centrifuged at $450 \mathrm{~g}$ at $4-6^{\circ} \mathrm{C}$ for $10 \mathrm{~min}$. Thereafter, the media were discarded and the cells were resuspended in $1 \mathrm{~mL}$ of fresh DM2 media for recounting by haemocytometer. Recoveries of cells at this stage averaged around $60 \%$. Subsequently, the individual cell concentrations were adjusted so that a final concentration of approximately 60,000 cells per culture was achieved. Any cell preparations with fewer numbers of cells than those allowed for one treatment, with the appropriate control, to be tested were discarded. The cells were then incubated in 48-well plates with or without FSH $(1000 \mathrm{ng} / \mathrm{mL})$ or hCG $(100 \mathrm{ng} / \mathrm{mL})$ in a final volume of $600 \mu \mathrm{L}$ in a $38^{\circ} \mathrm{C}$ water bath for $45 \mathrm{~min}$. The doses of FSH and hCG were selected to elicit maximal cAMP responses based on previous dose response studies in wild type, I+ and BB ewes (Henderson et al. 1989, McNatty et al. 1990, 2009, Shackell et al. 1993): from these dose response studies, no genotype differences were noted (Henderson et al. $1987,1989)$. Subsequently, the cultures were heated at $80^{\circ} \mathrm{C}$ for $15 \mathrm{~min}$. Samples were stored at $-20^{\circ} \mathrm{C}$ until assayed for CAMP by radioimmunoassay (RIA). The assay employed was that described previously by Jolly and coworkers (Jolly et al. 1997) using an in-house rabbit anti-0,2-monosuccinyl-3',

Table 2 Effect of genotype on mean \pm S.E.M. number of granulosa cells (in millions) with respect to follicular diameter in sheep.

\begin{tabular}{|c|c|c|c|c|c|}
\hline \multirow[b]{2}{*}{ Genotype $(n)$} & \multicolumn{5}{|c|}{ Follicular diameter (mm) } \\
\hline & $1-2$ & $>2-3$ & $>3-4$ & $>4-5$ & $>5$ \\
\hline$++(23)$ & $0.71 \pm 0.03^{\mathrm{a}}[120]$ & $1.29 \pm 0.05^{b}[103]$ & $1.88 \pm 0.16^{\mathrm{b}, \mathrm{c}}[23]$ & $3.12 \pm 0.51^{\mathrm{c}, \mathrm{d}}[8]$ & $4.29 \pm 0.24^{\mathrm{d}}[32]$ \\
\hline $\mathrm{I}+(10)$ & $0.61 \pm 0.02^{\mathrm{a}}[86]$ & $0.87 \pm 0.04^{b}[43]$ & $1.47 \pm 0.19^{b, c}[11]$ & $2.09 \pm 0.21^{\mathrm{c}, \mathrm{d}}[18]$ & $3.70 \pm 0.30^{\mathrm{d}}[10]$ \\
\hline $\mathrm{I}+\mathrm{B}+(7)$ & $0.41 \pm 0.03^{\mathrm{a}}[81]$ & $0.82 \pm 0.06^{b}[51]$ & $1.03 \pm 0.09^{b}[20]$ & $0.89 \pm 0.12^{b}[5]$ & $-[0]$ \\
\hline $\mathrm{I}+\mathrm{B}+\mathrm{W}+(10)$ & $0.35 \pm 0.01^{\mathrm{a}}[132]$ & $0.85 \pm 0.07^{b}[37]$ & $0.98 \pm 0.05^{b}[42]$ & $1.16 \pm 0.13^{b}[9]$ & $-[0]$ \\
\hline $\mathrm{BB}(3)$ & $0.36 \pm 0.03^{\mathrm{a}}[37]$ & $0.97 \pm 0.11^{b}[14]$ & $0.77 \pm 0.11^{\mathrm{b}}[7]$ & $1.20^{\mathrm{b}}[2]$ & $-[0]$ \\
\hline
\end{tabular}

$n$, number of ewes, $[n]$ refers to number of follicles. For each genotype separately, the granulosa cell numbers in each row not sharing an alphabetical superscript are significantly different from one another, $P<0.01$. 
5 -cyclic monophosphate antibody with the separation of bound and free CAMP involving the use of an in-house sheep anti-rabbit second antibody. The antibody crossreacted $9 \%$ with dibutyryl CAMP and $<0.0014 \%$ with cGMP and $<0.0001 \%$ with AMP, ADP or ATP. The detection limit was $0.2 \mathrm{pmol} / \mathrm{million}$ cells and the intra- and interassay coefficients of variation were both $<10 \%$. Follicles with granulosa cells producing cAMP $\geq 5 \mathrm{pmol} / 10^{6}$ cells in response to hCG were considered to be $\mathrm{LH}$ responsive (McNatty et al. 2009).

\section{Statistical procedures}

The data concerning the effect of genotype on ovulation rate and $\mathrm{CL}$ weight were analysed by ANOVA and when appropriate, the Newman-Keuls post hoc test was applied. For determining genotype differences in numbers of granulosa cells for a given follicular diameter, each follicle was considered a discrete variable irrespective of whether it was isolated from the same or a different animal. This was considered to be a valid assumption as few, if any, follicles were identical either in function or in composition within each animal (McNatty et al. 2010). Only follicles devoid of visible debris in follicular fluid and intact COC were used for the analyses of granulosa cell number and CAMP responsiveness. These data together with those for $\mathrm{LH}$ and $\mathrm{FSH}$ responsiveness were analysed by Kruskal-Wallis and the Dunn's multiple range test.

\section{Results \\ Effect of genotype on ovulation rate and the mean weight of corpora lutea (CL)}

These data are summarised in Table 1. The ovulation rate in Table 1 is based on the number of regressing CL at $24 \mathrm{~h}$ after inducing luteolysis with a PGF2 $\alpha$ derivative. The ovulation rate in $\mathrm{I}+\mathrm{B}+\mathrm{W}+$ ewes was equivalent to that in $\mathrm{BB}$ ewes and greater than that of $\mathrm{I}+\mathrm{B}+$ animals which in turn was greater than that in I+ and ++ genotypes. In contrast, the mean weight of each $C L$ was lighter in the $\mathrm{I}+\mathrm{B}+, \mathrm{I}+\mathrm{B}+\mathrm{W}+$ and $\mathrm{BB}$ animals compared to that in $\mathrm{I}+$ and ++ animals. For each genotype, the total weight of $\mathrm{CL}$ tissue per ewe was not different.

\section{Effect of genotype on the number (mean \pm S.E.M.) of follicles $\geq 1 \mathrm{~mm}$ diameter}

The numbers of follicles in,$++ \mathrm{I}+, \mathrm{I}+\mathrm{B}+, \mathrm{I}+\mathrm{B}+\mathrm{W}+$ and $B B$ genotypes $\geq 1 \mathrm{~mm}$ diameter were $31 \pm 3,36 \pm 4$, $38 \pm 4,34 \pm 6$ and $24 \pm 8$ respectively. These values were not significantly different from one another.

The effect of genotype on the mean \pm S.E.M. number of granulosa cells with respect to follicular diameter are summarised in Table 2 . In the ++ and I+ genotypes, the mean numbers of granulosa cells increased as follicular diameter increased with the highest mean numbers per follicle found in those $>4-5 \mathrm{~mm}$. Contrary to this pattern, for the $\mathrm{I}+\mathrm{B}+, \mathrm{I}+\mathrm{B}+\mathrm{W}+$ and $\mathrm{BB}$ genotypes,

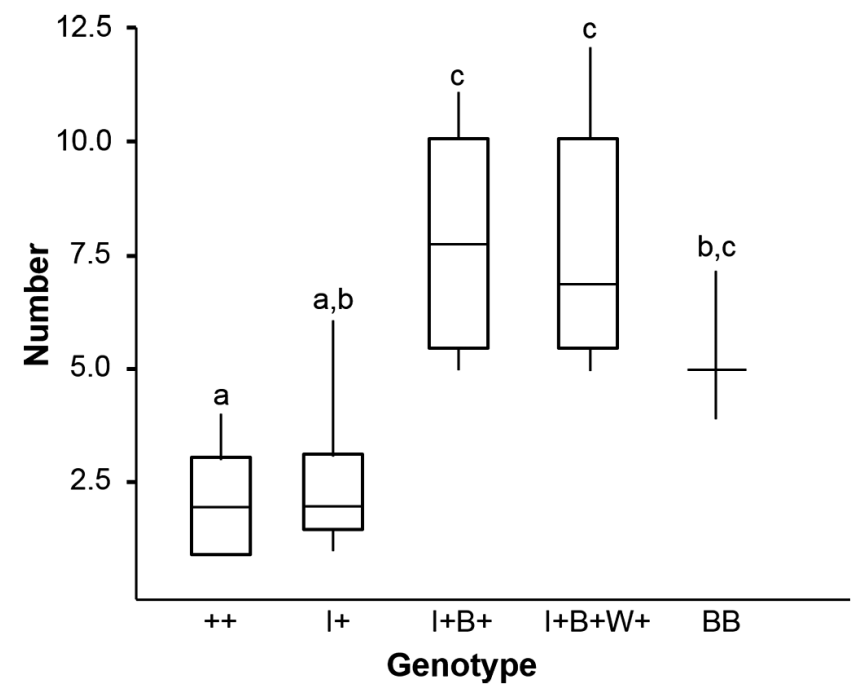

Figure 1 Number of follicles with LH-responsive granulosa cells represented by Box and Whisker plots. Box and Whisker plots with different alphabetical superscripts are significantly different from one another: avc, $P<0.001$; bvc, $P<0.01$; avc $P<0.05$. The plots indicate that in the $\mathrm{I}+\mathrm{B}+$ and $\mathrm{I}+\mathrm{B}+\mathrm{W}+$ genotypes, there were between 5 and 12 follicles that could be considered to be preovulatory, whereas in $\mathrm{BB}$, there were between 4 and 7 , in $1+$ between 1 and 6 and in the ++ between 1 and 4 .

the total number of granulosa cells increased when comparing 1-2 $\mathrm{mm}$ follicles with those $>2-3 \mathrm{~mm}$ but the total cell numbers plateaued thereafter. In these three genotypes, the highest mean numbers of granulosa cells per follicle were noted after follicles exceeded $2 \mathrm{~mm}$ diameter. Over all ranges of follicular diameters, the mean numbers of granulosa in I+ ewes

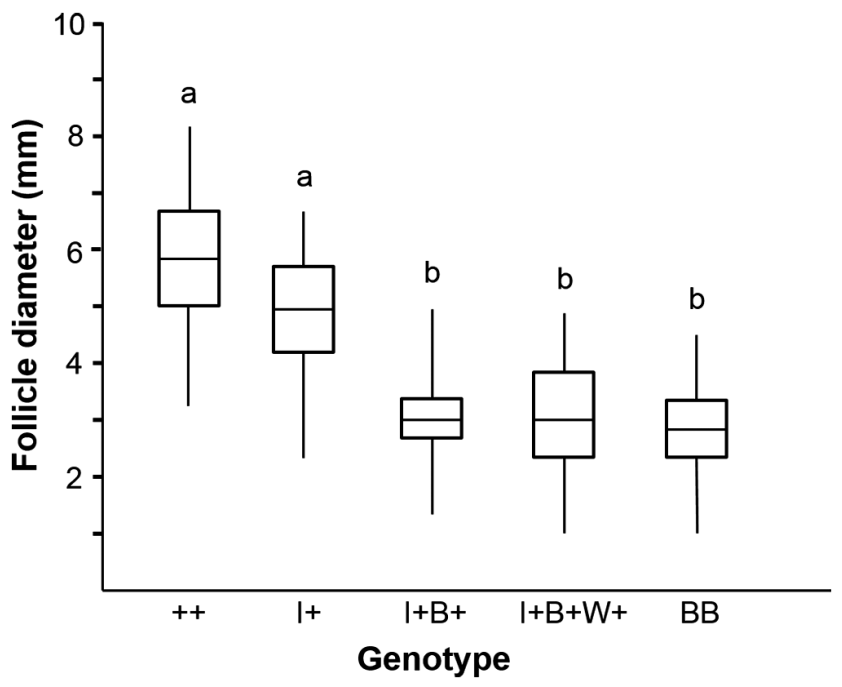

Figure 2 Effect of genotype on diameters of follicles with LH-responsive granulosa cells represented by Box and Whisker plots. Box and Whisker plots with different alphabetical superscripts are significantly different from one another, $P<0.01$. The plots indicate that $>75 \%$ of all LH-responsive follicles in the ++ and I+ genotypes are $>4 \mathrm{~mm}$ diameter, whereas in the $\mathrm{I}+\mathrm{B}+, \mathrm{I}+\mathrm{B}+\mathrm{W}+$ and $\mathrm{BB}$ ewes $>75 \%$ of all such follicles were $<4 \mathrm{~mm}$ diameter. 
Table 3 Effect of genotype on hCG- or FSH-induced cAMP synthesis by granulosa cells from the putative preovulatory follicles.

\begin{tabular}{lccccc}
\hline & \multicolumn{4}{c}{ Genotype } \\
\cline { 2 - 5 } Hormone & $++[41]$ & $\mathrm{I}+[24]$ & $\mathrm{I}+\mathrm{B}+[42]$ & $\mathrm{I}+\mathrm{B}+\mathrm{W}+[38]$ & $\mathrm{BB}[14]$ \\
\hline hCG & $14.1(10.6,18.1)$ & $12.1(9.3,18.0)$ & $10.1(8.4,12.2)$ & $10.8(9.0,13.1)$ & $10.6(7.8,14.5)$ \\
FSH & $7.7(5.7,10.3)$ & $6.4(4.4,9.4)$ & $4.4(3.7,5.3)$ & $6.1(4.4,8.3)$ & $4.5(3.2,6.3)$ \\
\hline
\end{tabular}

The cAMP values are expressed as pmol per $10^{6}$ cells. Values are geometric means (and 95\% confidence limits). Numbers in square brackets refer to the number of follicles.

were consistently lower than those in ++ animals. In the $\mathrm{I}+\mathrm{B}+, \mathrm{I}+\mathrm{B}+\mathrm{W}+$ and $\mathrm{BB}$ genotypes, the mean number of granulosa cells for each range of follicular diameter $(1-2,>2-3$ and $>3-4 \mathrm{~mm})$ were not different from one another: follicles $>5 \mathrm{~mm}$ were not observed. Moreover, for the $\mathrm{I}+\mathrm{B}+, \mathrm{I}+\mathrm{B}+\mathrm{W}+$ and $\mathrm{BB}$ genotypes, the mean numbers of granulosa cells in the largest follicles were about one-third of those accumulated in the largest follicles of the ++ and I+ ewes. Animals with the $\mathrm{W}+$ genotype were not available for inclusion in this study. Only two animals with the $\mathrm{W}+\mathrm{I}+$ genotype were investigated, and these two animals had ovulation rates of 8 and 4 and with the largest follicles reaching 5.0 and $5.3 \mathrm{~mm}$ in diameter and with granulosa cell numbers of 1.25 and 2.98 million respectively: these animals were not investigated further.

\section{Effect of genotype on the number of follicles with $L H$-responsive granulosa cells}

These data are summarised in Fig. 1. The median number of follicles with LH-responsive granulosa cell populations was highest in the $\mathrm{I}+\mathrm{B}+$ and $\mathrm{I}+\mathrm{B}+\mathrm{W}+$ genotypes compared to either the ++ or $\mathrm{I}+$ genotypes at $24 \mathrm{~h}$ after induction of a new follicular phase with a PGF2 $\alpha$ derivative. The number in the BB genotype was not different from $\mathrm{I}+, \mathrm{I}+\mathrm{B}+$ and $\mathrm{I}+\mathrm{B}+\mathrm{W}+$ but was significantly higher than that in $++(P<0.05)$.

\section{Effect of genotype on follicular diameter and total numbers of granulosa cells in follicles with LH-responsive granulosa cells}

The data with respect to the effect of genotype on follicular diameter are summarised in Fig. 2. The diameter of follicles in the $\mathrm{I}+\mathrm{B}+, \mathrm{I}+\mathrm{B}+\mathrm{W}+$ and $\mathrm{BB}$ genotypes were not different from one another but all were significantly lower than that in the ++ and I+ animals at $24 \mathrm{~h}$ after induction of a follicular phase with PGF $2 \alpha$. In the ,$++ \mathrm{I}+, \mathrm{I}+\mathrm{B}+, \mathrm{I}+\mathrm{B}+\mathrm{W}+$ and $\mathrm{BB}$ genotypes, the median diameters of $\mathrm{LH}$-responsive follicles were around 6, 5, 3,3 and $3 \mathrm{~mm}$ respectively. The geometric mean (and $95 \%$ confident limits) total number of LH-responsive granulosa cells over all follicles in each of the,$++ \mathrm{I}+$, $\mathrm{I}+\mathrm{B}+, \mathrm{I}+\mathrm{B}+\mathrm{W}+$ and $\mathrm{BB}$ genotypes was $6.5(5.4,7.9)$, $6.7(5.8,7.8), 5.7(3.9,8.4), 6.9(5.8,8.3)$ and 5.3 $(3.6,7.9)$ million cells respectively: these numbers were not significantly different from one another.
There were no significant differences between the genotypes with respect to the geometric mean (and 95\% confidence limits) levels of cAMP produced from the LH-responsive granulosa cells in the presumptive preovulatory follicles (Table 3 ).

\section{Effect of genotype on FSH responsiveness of granulosa cells}

Overall, there was no effect of follicular diameter (i.e. $1-2,>2-3,3->4,>4-5$ and $>5 \mathrm{~mm}$ ) on the maximal levels of cAMP synthesised in response to $\mathrm{FSH}$ in vitro. $\mathrm{In} \mathrm{I}+\mathrm{B}+$ and $\mathrm{I}+\mathrm{B}+\mathrm{W}+$ genotypes, there were no follicles $>5 \mathrm{~mm}$ diameter and for $\mathrm{BB}$, no follicles $>4 \mathrm{~mm}$ diameter were present. The only exception to this was noted for the ++ genotype where the mean FSH response from granulosa cells recovered from the $>5 \mathrm{~mm}$ diameter follicles was significantly greater than that from cells recovered from $1-2$ and $>2-3$ but not the $>3-4$ or $>4-5 \mathrm{~mm}$ diameter follicles $(P<0.05$; data not shown). In the $\mathrm{LH}$-responsive granulosa cell populations (i.e. the putative preovulatory follicles), there was no effect of genotype on the FSH-induced cAMP responses (Table 3).

\section{Discussion}

The ovulation rate in $\mathrm{I}+\mathrm{B}+$ animals was significantly higher than that in $\mathrm{I}+$ and ++ animals and intermediate between those for $\mathrm{I}+\mathrm{B}+\mathrm{W}+$ and $\mathrm{BB}$ genotypes. The incorporation of both the $\mathrm{I}+$ and $\mathrm{B}+$ mutations within an animal appeared to be at least additive for ovulation rate and similar to that noted previously by Davis and coworkers (Davis et al. 1999). Animals with the $\mathrm{W}+$ genotype have a mean ovulation rate that is $\sim 25 \%$ above that of the wild type (Davis et al. 2001). In the present study, animals that contained the $\mathrm{W}+$ together with the $\mathrm{I}+$ and $\mathrm{B}+$ polymorphisms were found to have an ovulation rate that was $45 \%$ above that of the $\mathrm{I}+\mathrm{B}+$ animals indicating that the inclusion of $\mathrm{W}+$ was at least additive. As mentioned earlier, W+ genotype animals were not available for inclusion in this study and only two $\mathrm{W}+\mathrm{I}+$ animals were available. However, from examining the ovaries from these animals (i.e. ovulation rate, the size of the largest follicles and numbers of granulosa cells), the evidence suggests that these were intermediary in ovarian phenotype between I+ and $\mathrm{I}+\mathrm{B}+$ animals. 
The key findings from this study were that the ovarian characteristics in $\mathrm{I}+\mathrm{B}+$ and $\mathrm{I}+\mathrm{B}+\mathrm{W}+$ compared to the ++ genotype, as assessed by the responsiveness of granulosa cells to $\mathrm{LH}$, were indicative of follicles maturing at significantly smaller diameters. This finding is consistent with previous studies examining ovarian characteristics of the $\mathrm{B}+, \mathrm{I}+$ and $\mathrm{W}+$ genotypes separately (McNatty et al. 1986, Shackell et al. 1993, Feary et al. 2007), with the responses of individual mutations being less apparent than those observed in ewes with multiple mutations. The more dramatic effects observed in ewes with multiple mutations is likely caused by the additive, or potentially synergistic, influences of the BMP15, BMPR1B and $W+$ mutations (Juengel et al. 2013).

The number of putative ovulatory follicles in the different genotypes at $24 \mathrm{~h}$ after an induced luteolysis, as assessed by the numbers of follicles with $\mathrm{LH}$-responsive granulosa cells, was consistent with the ovulation rate determined from the previous cycle. An exception to this might have occurred for the BB animals in that the number of putative preovulatory follicles varied from 4 to 7 , whereas the number of corpora albicans from the previous cycle varied from 8 to 11 . Nevertheless, the presence of 4-7 putative preovulatory follicles lies within the range of ovulation rates observed in this flock of Booroola ewes. Importantly, all animals in this study contained follicles with LH-responsive granulosa cells. In the $\mathrm{I}+\mathrm{B}+$ and $\mathrm{I}+\mathrm{B}+\mathrm{W}+$ animals, the maximum number of granulosa cells accumulated in individual follicles was achieved when follicles exceeded $2 \mathrm{~mm}$ in diameter. Moreover, in these animals, the largest follicles at $24 \mathrm{~h}$ after PGF2 $\alpha$ treatment never exceeded $5 \mathrm{~mm}$ diameter: this was similar to that observed for the $B B$ animals. Moreover, the diameters of follicles in the $\mathrm{I}+\mathrm{B}+, \mathrm{I}+\mathrm{B}+\mathrm{W}+$ and $\mathrm{BB}$ genotypes when $\mathrm{LH}$ responsiveness was acquired in the granulosa cells, occurred between 1.2 and $5.0 \mathrm{~mm}$ in diameter. In $\mathrm{I}+$ and ++ animals, $\mathrm{LH}$ responsiveness was identified in follicles between 2.3 and $6.4 \mathrm{~mm}$ and 3.1 and $8.2 \mathrm{~mm}$ respectively. Despite the greater number of putative preovulatory follicles in $\mathrm{I}+\mathrm{B}+, \mathrm{I}+\mathrm{B}+\mathrm{W}+$ and $\mathrm{BB}$ relative to the $\mathrm{I}+$ and ++ genotypes, the total numbers of LH-responsive granulosa cells between these genotypes when added together were not different from one another. The geometric mean cAMP responses $/ 10^{6}$ granulosa cells in response to $\mathrm{LH}$ also did not differ between the genotypes. And, no differences in $\mathrm{FSH}$ induced cAMP responses were noted in these putative preovulatory follicles. Collectively, these observations indicate that despite the high ovulation rates in $\mathrm{I}+\mathrm{B}+$ and $\mathrm{I}+\mathrm{B}+\mathrm{W}+$ animals, the overall level of ovarian endocrine signalling with respect to hormones such as oestradiol, inhibin and progesterone secretion is likely to be similar to that in the BB genotype and not different from that noted for ++ animals with ovulation rates of 1 or 2 (McNatty et al. 1986, 1992, Niswender et al. 1990).

When using a highly purified FSH preparation, devoid of LH contamination, there was no evidence to indicate that the higher proportion of follicles with LH-responsive granulosa cells in I+ compared to ++ ewes was associated with any genotype difference in FSH responsiveness (McNatty et al. 2009): this was in contrast to an earlier report when a less pure preparation of FSH was used (Shackell et al. 1993). Using the same highly purified $\mathrm{FSH}$ (and $\mathrm{LH}$-free) preparation in the present study as reported by McNatty and coworkers (McNatty et al. 2009), no differences in FSH-induced CAMP responsiveness with respect to follicular diameter was noted for the $\mathrm{I}+\mathrm{B}+, \mathrm{I}+\mathrm{B}+\mathrm{W}+$ or $\mathrm{BB}$ ewes. The only exception to this was an effect noted in the ++ animals whereby the cAMP response to $\mathrm{FSH}$ was greater in $>5$ compared to $1-3 \mathrm{~mm}$ diameter follicles. This raises the possibility of an effect of $\mathrm{FSH}$ with respect to follicular diameter in the $\mathrm{I}+, \mathrm{I}+\mathrm{B}+, \mathrm{I}+\mathrm{B}+\mathrm{W}+$ and $\mathrm{BB}$ genotypes but that this might occur in follicles $<1 \mathrm{~mm}$ diameter. However, it is worth noting that the effect of follicular diameter on FSH-induced cAMP production has not been consistently observed. Previous studies that used highly purified FSH, devoid of $\mathrm{LH}$, were unable to observe any effect on follicular diameter in $\geq 1 \mathrm{~mm}$ diameter follicles in ++ ewes (McNatty et al. 2009, Crawford et al. 2011, Juengel et al. 2011).

In a physiological context, the ovulation rates in $\mathrm{I}+\mathrm{B}+$ and $\mathrm{I}+\mathrm{B}+\mathrm{W}+$ ewes are superior to those achieved using superovulation regimes. For example, after a superovulation treatment in wild-type Romney ewes, the range of follicular diameters in follicles with LH-responsive granulosa cells with respect to CAMP synthesis was between 2 and $9.5 \mathrm{~mm}$ (McNatty et al. 2010). Moreover, the number of LH-responsive follicles varied between 1 and 10 and the total number of granulosa cells when added together from these putative preovulatory follicles varied between 3.2 and $13.6 \times 10^{6}$. Sheep, during a superovulation regimen, using exogenous $\mathrm{FSH}$-rich preparations, acquire $\mathrm{LH}$-responsive follicular granulosa cells in follicles $>1 \mathrm{~mm}$ diameter (McNatty et al. 1993). Given that each of these follicles will accumulate between $1 \times 10^{6}$ and $6 \times 10^{6}$ granulosa cells, it becomes evident that as the ovulation rate increases, the total weight of the ovaries and the total accumulated masses of follicular cells increases with concomitant increases in ovarian hormone secretion. Given the high variability in subsequent pregnancy or embryo transfer success, it is reasonable to assume that the increase in preovulatory follicular development may not always be accompanied by a concomitant and synchronous maturation of oocytes. This is in contrast to what happens in $\mathrm{I}+\mathrm{B}+, \mathrm{I}+\mathrm{B}+\mathrm{W}+$ and $\mathrm{BB}$ ewes where the high ovulation rates are achieved without altering the total number of granulosa cells from all ovulatory follicles or luteal cell masses and with a high level of repeatability in individual animals. Moreover, as indicated previously, this is most likely achieved without increasing the net ovarian secretions of oestradiol, inhibin or progesterone as these are highly correlated with the 
number of granulosa or luteal cells (McNatty et al. 1986, 1993, Niswender et al. 1990, Shackell et al. 1993). Importantly, the evidence from embryo transfer studies in the $\mathrm{I}+\mathrm{B}+$ and $\mathrm{I}+\mathrm{B}+\mathrm{W}+$ ewes indicates that the yields of good quality embryos are high. In I+B+ donors $(n=9)$ with a mean \pm S.E.M. ovulation rate of $7.8 \pm 0.4$, the number of embryos recovered was $5.9 \pm 0.6$. In $\mathrm{I}+\mathrm{B}+\mathrm{W}+$ donors $(n=9)$, the mean \pm S.E.M. ovulation rate was $9.0 \pm 0.7$ and the mean \pm S.E.M. embryo recovery was $5.8 \pm 0.9$, with one ewe producing no viable embryos (JL Juengel, AR O'Connell \& LD Quirk, Unpublished observations, Juengel et al.). It is also reasonable to propose that the superior 'superovulation-like' outcome in these genotypes is due to a lower concentration of oocyte-derived BMP15 as this effect can be replicated, at least in part, by partial immuno-neutralisation of BMP15 (Juengel et al. 2002). It is also of interest to note that applying a superovulation treatment to ewes immunised against BMP15, to partially neutralise this secreted growth factor, does not further advance ovulation rate (Juengel et al. 2011).

In summary, these unique sheep models provide evidence in support of the hypothesis that lowering endogenous BMP15 concentrations, perhaps by the application of long-acting BMP15 antagonists, might be an attractive alternative to exogenous gonadotrophins for generating consistently high embryo yields (McNatty et al. 2014).

\section{Declaration of interest}

The authors declare that there is no conflict of interest that could be perceived as prejudicing the impartiality of the research reported.

\section{Funding}

This work was funded, in part, by Royal Society of New Zealand and the Marsden Fund Grants 011-VUW-010 and 13-VUW-153. Funding was also received from the New Zealand Ministry of Business, Innovation \& Employment (formerly Foundation for Research, Science \& Technology), New Zealand (grant number C10X1001) and AgResearch Core Funding.

\section{Acknowledgements}

The authors wish to acknowledge Laurel Quirke for assistance in the laboratory and ovarian collections. The authors would also like to acknowledge the members of the Invermay Reproduction Team and Invermay farm staff for help with animal care and handling.

\section{References}

Campbell BK, Souza CJ, Skinner AJ, Webb R \& Baird DT 2006 Enhanced response of granulosa and theca cells from sheep carriers of the
FecB mutation in vitro to gonadotropins and bone morphogenetic protein-2, -4, and -6. Endocrinology 147 1608-1620. (doi:10.1210/ en.2005-0604)

Crawford JL \& McNatty KP 2012 The ratio of growth differentiation factor 9: bone morphogenetic protein $15 \mathrm{mRNA}$ expression is tightly co-regulated and differs between species over a wide range of ovulation rates. Molecular and Cellular Endocrinology 348 339-343. (doi:10.1016/j.mce.2011.09.033)

Crawford JL, Heath DA, Reader KL, Quirke LD, Hudson NL, Juengel JL \& McNatty KP 2011 Oocytes in sheep homozygous for a mutation in bone morphogenetic protein receptor 1B express lower mRNA levels of bone morphogenetic protein 15 but not growth differentiation factor 9 . Reproduction 142 53-61. (doi:10.1530/REP-10-0485)

Davis GH 2005 Major genes affecting ovulation rate in sheep. Genetics Selection Evolution 37 (Supplement 1) S11-S23. (doi:10.1186/12979686-37-S1-S11)

Davis GH, Dodds KG \& Bruce GD 1999 Combined effect of the Inverdale and Booroola fecundity genes on ovulation rate in sheep. Proceedings of the Association for the Advancement of Animal Breeding Genetics $1374-77$.

Davis GH, Dodds KG, Wheeler R \& Jay NP 2001 Evidence that an imprinted gene on the $X$ chromosome increases ovulation rate in sheep. Biology of Reproduction 64 216-221. (doi:10.1095/biolreprod64.1.216)

Davis GH, Galloway SM, O'Connell A, Farquhar PA, McNatty KP \& Juengel JL 2008 Hyper-prolific ewes carrying copies of three major genes: a model for studying genes controlling ovulation rate. Biology of Reproduction $\mathbf{7 8} 110$ abstract 244.

Fabre S, Pierre A, Pisselet C, Mulsant P, Lecerf F, Pohl J, Monget P \& Monniaux D 2003 The Booroola mutation in sheep is associated with an alteration of the bone morphogenetic protein receptor-1B functionality. Journal of Endocrinology 177 435-444. (doi:10.1677/joe.0.1770435)

Feary ES, Juengel JL, Smith P, French MC, O'Connell AR, Lawrence SB, Galloway SM, Davis GH \& McNatty KP 2007 Patterns of expression of messenger RNAs encoding GDF9, BMP15, TGFBR1, BMPR1B and $B M P R 2$ during follicular development and characterization of ovarian follicular populations in ewes carrying the Woodlands FecX2 ${ }^{W}$ mutation. Biology of Reproduction 77 990-998. (doi:10.1095/ biolreprod.107.062752)

Fidler AE, Lin JS, Lun S, Ng Chie W, Western A, Stent V \& McNatty KP 2003 Production of biologically active tethered ovine $\mathrm{FSH} \beta \alpha$ by the methylotrophic yeast Pichia pastoris. Journal of Molecular Endocrinology 30 213-225. (doi:10.1677/jme.0.0300213)

Henderson KM, Kieboom LE, McNatty KP, Lun S \& Heath D 1987 Gonadotrophin-stimulated cyclic AMP production by granulosa cells from Booroola x Romney ewes with and without a fecundity gene. Journal of Reproduction and Fertility 75 111-120. (doi:10.1530/ jrf.0.0750111)

Henderson KM, McNatty KP, O'Keefe LE, Lun S, Heath DA \& Prisk MD 1989 Differences in gonadotrophin-stimulated CAMP production by granulosa cells from Booroola x Merino ewes which were homozygous, heterozygous or non-carriers of a fecundity gene influencing their ovulation rate. Journal of Reproduction and Fertility 81 395-402. (doi:10.1530/jrf.0.0810395)

Hosoe M, Kaneyama K, Ushizawa K, Hatashi K-G \& Takahashi T 2011 Quantitative analysis of bone morphogenetic protein 15 (BMP15) and growth differentiation factor 9 (GDF9) gene expression in calf and adult ovaries. Reproductive Biology and Endocrinology 933. (doi:10.1186/1477-7827-9-33)

Jolly PD, Tisdall DJ, De'ath G, Heath DA, Lun S, Hudson NL \& McNatty KP 1997 Granulosa cell apoptosis, aromatase activity, cyclic adenosine 3',5'-monophosphate response to gonadotropins and follicular fluid steroid levels during spontaneous and induced follicular atresia in ewes. Biology of Reproduction 56 830-836. (doi:10.1095/ biolreprod56.4.830)

Juengel JL, Hudson NL, Heath DA, Smith P, Reader KL, Lawrence SB, O'Connell AR, Laitinen MP, Cranfield M, Groome NP et al. 2002 Growth differentiation factor 9 and bone morphogenetic protein 15 are essential for ovarian follicular development in sheep. Biology of Reproduction 67 1777-1789. (doi:10.1095/biolreprod.102.007146)

Juengel JL, Hudson NL, Whiting L \& McNatty KP 2004 Effects of immunization against bone morphogenetic protein 15 and growth differentiation factor 9 on ovulation rate, fertization, and pregnancy in ewes. Biology of Reproduction 70 557-561. (doi:10.1095/biolreprod.103.023333) 
Juengel JL, Quirke LD, Lun S, Heath DA, Johnson PD \& McNatty KP 2011 Effects of immunizing ewes against bone morphogenetic protein 15 on their responses to exogenous gonadotrophins to induce multiple ovulations. Reproduction 142 565-572. (doi:10.1530/REP-11-0126)

Juengel JL, Davis GH \& McNatty KP 2013 Using sheep lines with mutations in single genes to better understand ovarian function. Reproduction $\mathbf{1 4 6}$ R111-R123. (doi:10.1530/REP-12-0509)

McNatty KP, Lun S, Heath DA, Ball K, Smith P, Hudson, NL, McDiarmid J, Gibb M \& Henderson KM 1986 Differences in ovarian activity between booroola $\mathrm{x}$ merino ewes which were homozygous, heterozygous and non-carriers of a major gene influencing their ovulation rate. Journal of Reproduction and Fertility 77 193-205. (doi:10.1530/jrf.0.0770193)

McNatty KP, Lun S, Heath DA, Hudson NL, O'Keefe LE \& Henderson KM 1989 Binding characteristics of 125I-labelled human FSH to granulosa cells from Booroola ewes which were homozygous, heterozygous or non-carriers of a major gene(s) influencing their ovulation rate. Journal of Reproduction and Fertility 86 27-38. (doi:10.1530/jrf.0.0860027)

McNatty KP, Lun S, Hudson NL \& Forbes S 1990 Effects of follicle stimulating hormone, cholera toxin and forskolin on adenosine cyclic 3', 5'-monophosphate output by granulosa cells from Booroola ewes with or without the $\mathrm{F}$ gene. Journal of Reproduction and Fertility $\mathbf{8 9}$ 553-563. (doi:10.1530/jrf.0.0890553)

McNatty KP, Heath DA, Hudson NL, Ball K \& Condell L 1992 Concentrations of immunoreactive inhibin in ovarian and peripheral venous plasma and follicular fluid of Booroola ewes that are homozygous or non-carriers of the FecB gene. Journal of Reproduction and Fertility 95 489-502. (doi:10.1530/jrf.0.0950489)

McNatty KP, Hudson NL, Heath DA, Shaw L, Blay L, Berry L \& Lun S 1993 Effect of chronic FSH administration on ovarian follicular development, ovulation rate and corpora lutea formation in sheep. Journal of Endocrinology 138 315-325. (doi:10.1677/joe.0.1380315)

McNatty KP, Heath DA, Hudson NL, Lun S, Juengel JL \& Moore LG 2009 Gonadotrophin-responsiveness of granulosa cells from bone morphogenetic protein 15 heterozygous mutant sheep. Reproduction 138 545-551. (doi:10.1530/REP-09-0154)

McNatty KP, Heath DA, Hudson NL, Reader KL, Quirke L, Lun S \& Juengel JL 2010 The conflict between hierarchical ovarian follicular development and superovulation treatment. Reproduction $\mathbf{1 4 0}$ 287-294. (doi:10.1530/REP-10-0165)

McNatty KP, Juengel JL \& Pitman JL 2014 Oocyte-somatic cell interactions and ovulation rate: effects on oocyte quality and embryo yield. Reproductive Biology Insights 7 1-8. (doi:10.4137/RBI.S12146)

Mester B, Ritter LJ, Pitman JL, Bibby AH, Gilchrist RB, McNatty KP, Juengel JL \& McIntosh CJ 2015 Oocyte expression, secretion and somatic cell interaction of mouse bone morphogenetic protein 15 during the peri-ovulatory period. Reproduction, Fertility and Development 27 801-811. (doi:10.1071/RD13336)
Moore LG, Ng Chie W, Lun S, Lawrence SB, Young W \& McNatty KP 1997 Follicle stimulating hormone in the brushtail possum (Trichosaurus vulpecula): purification, characterization and radioimmunoassay. General and Comparative Endocrinology 106 30-38. (doi:10.1006/gcen.1996.6847)

Niswender GD, McNatty KP, Smith P, Niswender KD, Farin CE \& Sawyer HR 1990 Numbers of steroidogenic luteal cells in Booroola Merino sheep. Journal of Reproduction and Fertility 90 185-190. (doi:10.1530/ jrf.0.0900185)

Paradis F, Novak S, Murdoch GK, Dyck MK, Dixon WT \& Foxcroft GR 2009 Temporal regulation of BMP2, BMP6, GDF9, BMPR1A, BMPR1B, $B M P R 2$ and TGFBR1 mRNA expression in the oocyte, granulosa and theca cells of developing preovulatory follicles in the pig. Reproduction 138 115-129. (doi:10.1530/REP-08-0538)

Souza CJ, McNeilly AS, Benavides MV, Melo EO \& Moraes JC 2014 Mutation in the protease cleavage site of GDF9 increases ovulation rate and litter size in heterozygous ewes and causes infertility in homozygous ewes. Animal Genetics 45 732-739. (doi:10.1111/age.12190)

Wilson T, Wu XY, Juengel JL, Ross IK, Lumsden JM, Lord EA, Dodds KG, Walling GA, McEwan JC, O'Connell AR et al. 2001 Highly prolific Booroola sheep have a mutation in the intracellular kinase domain of bone morphogenetic protein 1B receptor (ALK6) that is expressed in both oocytes and granulosa cells. Biology of Reproduction 64 1225-1335. (doi:10.1095/biolreprod64.4.1225)

Webb R \& England BG 1982 Identification of the ovulatory follicle in the ewe: associated changes in follicular size, thecal and granulosa cell luteinizing hormone receptors, antral fluid steroids and circulating hormones during the preovulatory period. Endocrinology 110 873-881. (doi:10.1210/endo-110-3-873)

Shackell GH, Hudson NL, Heath DA, Lun S, Shaw L, Condell L, Blay LR \& McNatty KP 1993 Plasma gonadotropin concentrations and ovarian characteristics in Inverdale ewes that are heterozygous for a major gene $\left(\right.$ Fec $\left.X^{\prime}\right)$ on the $\mathrm{X}$ chromosome that influences ovulation rate. Biology of Reproduction 48 1150-1156. (doi:10.1095/biolreprod48.5.1150)

Silva JRV, Van Den Hurk R, Van Tol HTA, Roelen BAJ \& Figueiredo JR 2004 Expression of Growth Differentiation Factor 9 (GDF9), Bone Morphogenetic Protein 15 (BMP15), and BMP receptors in the ovaries of goats. Molecular Reproduction and Development 70 11-19. (doi:10.1002/mrd.20127)

Received 27 July 2016

First decision 8 September 2016

Revised manuscript received 31 October 2016

Accepted 25 November 2016 